This article was downloaded by: [Memorial University of Newfoundland]

On: 20 January 2015, At: 12:17

Publisher: Routledge

Informa Ltd Registered in England and Wales Registered Number: 1072954

Registered office: Mortimer House, 37-41 Mortimer Street, London W1T

3J H, UK

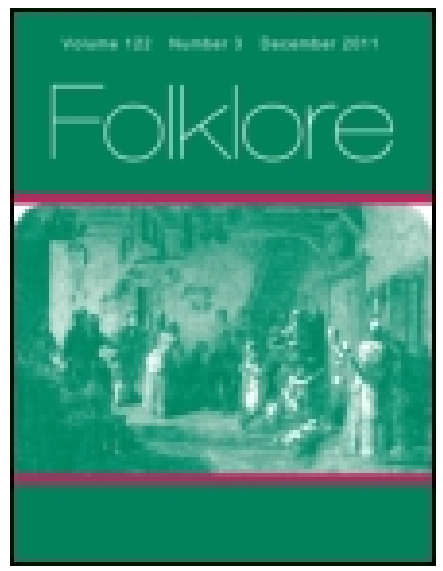

\title{
Folklore
}

Publication details, including instructions for authors and subscription information:

http:// www. tandfonline.com/loi/ rfol20

\section{The Cults of the Mother Goddesses in India.}

W. Crooke

Published online: 01 Feb 2012.

To cite this article: W. Crooke (1919) The Cults of the Mother Goddesses in India., Folklore, 30:4, 282-308, DOI: 10.1080/ 0015587X. 1919.9719110

To link to this article: http:// dx.doi.org/ 10.1080/ 0015587X.1919.9719110

\section{PLEASE SCROLL DOWN FOR ARTICLE}

Taylor \& Francis makes every effort to ensure the accuracy of all the information (the "Content") contained in the publications on our platform. However, Taylor \& Francis, our agents, and our licensors make no representations or warranties whatsoever as to the accuracy, completeness, or suitability for any purpose of the Content. Any opinions and views expressed in this publication are the opinions and views of the authors, and are not the views of or endorsed by Taylor \& Francis. The accuracy of the Content should not be relied upon and should be independently verified with primary sources of information. Taylor and Francis shall not be liable for any losses, actions, claims, proceedings, demands, costs, expenses, damages, and other liabilities whatsoever or howsoever caused arising directly or indirectly in connection with, in relation to or arising out of the use of the Content.

This article may be used for research, teaching, and private study purposes. Any substantial or systematic reproduction, redistribution, reselling, loan, sub-licensing, systematic supply, or distribution in any form to anyone is 
expressly forbidden. Terms $\&$ Conditions of access and use can be found at http://www.tandfonline.com/page/terms-and-conditions 


\title{
THE CULTS OF THE MOTHER GODDESSES IN INDIA.
}

\author{
HY w. CKOOKt.
}

(Read at the Meeting of the British Association, Bournemouth, it th September, 1919.)

BeIIIND many divine impersonations of the Minoan and early Hellenic theogonies appears the majestic figure of the Great Mother, who is generally benevolent. "Just as the mother," says Dr. Farnell, "frequently stands between the children and the father as the mild intercessor, so the goddess often becomes the mediator of mercy to whom the sinners turn as their intercessor with the offended god. Such was Isis for the Gracco-Roman world; such at times was Athena for the Athenians; such is the Virgin for Mediterranean Christendom." 1 But the range of the Mother cult extends beyond the Mediterranean area, in forms like those of Nina or Ishtar in Babylonia, Ashtoreth, sister of Ishtar, among the Western Semites, the great Hittite Goddess of Boghaz-Keui." As regards the Western Aryans, mythographers seem generally to have reached the conclusion that goddesses of this class should not be regarded as aliens, borrowed from the pre-Aryan races in whose lands they settled, and that, as the cults of Mother Earth prevailed widely in Europe, deities like Dione, Demeter, Hera and Hestia may be accepted as old Hellenic

'Greece and Babjlon, 82.

- Sir J. G. Frizer, Tha Golden Bough, 3rd ed. Adowis, Altis, Osin is, 1. 128 et sequ. 


\section{The Cults of the Mother Goddesses in India 283}

goddesses. " "The nature-worship of the Hellenes was pre-eminently concerned with Mother-earth-with Ge-meter, and this divine power in its varied personal forms was perhaps of all others the nearest and dearest to the popular heart: so much of their ritual was concerned directly with her. And some scholars have supposed, erroneously, I think, but not unnaturally, that all the leading Hellenic goddesses arose from this aboriginal animistic idea."

At present our knowledge of these primitive Mother deities is far from being complete. As their cults and that of Mother Earth are widespread in India, it may be worth considering whether a description of them may throw some much-needed light on the origin and development of the Western Mothers.

The question of the transmission of culture is still a subject of active controversy, and I shall not attempt to decide whether India and the Mediterranean are in any true sense contiguous cultures. It may be admitted that the quest of the precious metals or minerals, incense, pepper and many other things may have led to early trade intercourse by the Red Sea route. But I do not think that any scholar, in the present state of our knowledge, would be inclined to trace much connexion in theology or ritual between India and Egypt. The case of the relations of India to Babylonia, the latter country forming a link with the West, is still obscure. There appears to be no Indian deity who can be compared with the Babylonian En-lil or Bel of Nippur, conceived as the god of earth par excellence; Mesopotamian religion has no parallel figure to the Grecian Ge, and though Ishtar possessed vegetative

\footnotetext{
'Farnell, of. cit. 94 et sey.
}

Ibid. II 4 ; Id, Cults of the Greek States, lii. I at segg., and compare Miss J. l. Ilarrison, Journal HellenictSociely, xix. (1899), 205, 208, 220 ef seg.

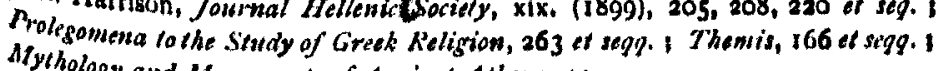
Atychologs and Monuments of Ancicut Athons, 44. 


\section{The Cults of the Mother Goddesses in India.}

functions, it would be hazardous to say that she was a personal form of Earth. ${ }^{1}$

The study of the Indian Mother cults is for many reasons ifficult. In their earliest forms they are aniconic and un: 0 -ordinated, and literary evidence of the more primitive Dravidian cults is, of course, wanting. When they have been taken over by the Brähmans they have been so worked over and metamorphosed that many of their original features are now unintelligible. When these deitics influence fertility the cultus is to a large extent magical, and as magic necessarily involves secrecy, enquirers of a different faith are unable to investigate it. In the case of Saktism, the latest development, these difficulties are increased, because the worship of the female productive energies offends the nobler and more sober instincts of Hindus, and the rites are necessarily conducted with precautions against the intrusion of outsiders in the mysteries.

When we compare the Aryan and Dravidian pantheons in India an important difference at once attracts attention." In Vedic belief and ritual goddesses occupy a very subordinate position, they play hardly any part as rulers of the world, and only two-Ushas, the spirit of the dawn, and Sarasvati, originally the impersonation of a sacred riveracquired special importance." In the same way, in Babylonia, except Ishtar, the goddesses are not very imposing figures, their characteristics are not sharply defined or differentiated, and their position conforms to the low conception of women in that civilisation." In the modern

1. Jf. Jastrow, The Keligion of Babylonia and Assyria, 140; L. W. King. Babylcnian Keligion and M/ythology, 10, 17 ; L. R. Farnell, Grecce and Babylon, 114. On Babylonian influence in India, see A. A. Macdonell, A. B. Keith, Vedic India, i. 430 et seq., ii. 128 et seq. 432.

"The distinctive difference between the Aryans and the Dasyu was one of religion-Macdonell-Keith, Vedic Index, i. 347, 357.

${ }^{3}$ A. A. Macdonell, Vedic $M / j$ thology, 124 et seq.; Sir R. G. Bhandarkar, V'aismavism, Saivism, and Mlinor Religions Systems, 142 et seqg.

1 I. W. King, op. cit. 22 et seg. 
orthodox Brahmanical pantheon the male deities are also predominant, and their consorts, except in the cases of figures like Kãlī, Durgā, or Devĩ, are of secondary importance. But in the old Dravidian pantheon which has survived in Southern India the leading feature is the worship of the female principle in nature, and it is only in the Brahman-ridden Tamil country that male deities acquire prominence over the goddesses. ${ }^{1}$ The important, fundamental conception of Dyaus, the Sky-god, and Prithivi, "the broad one," the impersonation of the widespread northern plains, does appear in the Vedas, but this bears little relation to the worship of Mother Earth among the Indo-Aryan and Dravidian peoples." In the Vedas "the Earth herself makes no remarkable figure: she is indeed deified, at least partially, is addressed as mother and substance of all things : is generally, in company with the sky, invoked to grant blessings; yet this never advanced further than a lively personation might go." "

In the later Hindu cults, however, that of Mother Earth has acquired great importance. She now takes the name, not of Prithivi, evpúarepvos of the Greeks, but of Bhümi, "that which is produced, exists," or more generally of Dharti, Dharani, Dharitri, "she who bears or carries," the upholder of the human, animal and vegetable creation which rests upon her surface. As a Grāmadevatã or village goddess she is generally aniconic, being supposed to dwell in a pile of rough stones or potsherds collected under

\footnotetext{
'Bishop H. Whitehead, The Village Gods of South India, 17, 94.

Macilonell, op. cit. 8, 12 ; [Sir] E. B. Tylor, Primitive Cullure, 2nd ed. 1. 321 et seqg. : G. Oppert, The Original Inhabilants of Bharatavarsa or India, 402 ; A. A. Macdonell, A. 13. Keith, Vedic Index, ii. 16 at seg.

"W. D. Whitney, Oriental and Linguistic Studies, 32. "The early Iranians personified Mother Earth as Spenta-Armaiti, the Aramatl of the Vedas" (M. Ilaug, Essays on the Sacred Langugg, Wrilings, and Kitigion of the Parsis, 160, 274, 306; M. Geiger, Civilisation of tho Eastern Irantanss in Ancient Times, i. Iutrod. xxxvii. et seq. 128 at seq. ; A. A. Macdonell, Vedic Abthology, ing at seg.)
} 


\section{The Cults of the Mother Goddesses in India.}

the sacred tree of the community. Her cultus is of primitive simplicity: she is chiefly worshipped by women, and if she has a priest he is usually not a Brähman, but drawn from the menials or outcastes. In south India Brăhmans object to serve the Mothers because they cannot join in their animal sacrifices. ${ }^{1}$ In northern India her offerings consist usually of grain or fruit laid on her stones or of milk poured over them. The Orāon farmer, before transplanting his rice seedlings, makes a libation of rice-beer on the ground, and prays to Dharti Māi : "O Mother Earth ! May we have plenty of rain and a bumper crop! Here is a drink-offering for thee!" " The forest-dwelling Kharwär in Mirzapur, who now lives chiefly by farming, prays : "O Mother Earth! Keep in prosperity and protect the ploughman and his oxen I" while in the Panjāb the prayer runs: "Keep our rulers and bankers contented I Grant us a plentiful yield! So shall we pay our revenue and satisfy our banker"-the sinister figure who haunts the dreams of the struggling peasant. ${ }^{8}$

In the Vedas she is invoked to shelter the corpse as it is laid in the grave. "Go thou now to Mother Earth, who is wide-opened, favourable, a wool-soft maiden to the good man. May she guard thee from the lap of destruction! Be not oppressive to him, let him enter easily, may he fasten close to thee !"; or, as it runs in the Atharva-veda, "Be pleasant to him, O Earth, a thornless resting-place: furnish him with a broad refuge! I cover thee excellently with the garment of Mother Earth ! Thou being earth, I make thee enter into earth !" " The Rauls of Poona at the present day, who bury their dead, say: "O Mother Earth 1 we make this body over to thee in the presence of the gods Brahma and Vishnu, who are our witnesses."

1 Bishop II. Whitehead, op. cit. 41.

- Sarat Chandra Ray, The Orions of Chota Nastur, 142.

- W. Crooke, Popular A'cligion and fiolstore of Northern India, i. 32 at sey.

- Nig.Veda, x. 18: Atharvaveda, xviii. 2, 4, trans. W. D. Whitney, ii. 836, $843,88.3$. The word for "earth" is here bhimini. 
Here the primitive animistic belief has been worked over by Brahmanism.

So far we have been considering the cultus in its most primitive type : but the oriental tendency towards anthropomorphism rapidly begins to affect it, and the representation of the goddess develops into the iconic stage. The southern Mother, Ellamma, is depicted rising from the earth as in the Buddhist sculptures the Earth Goddess emcrges from the earth to support the horse on which Gautama rides, when he leaves his wife and home and makes the Great Renunciation, and in Greek art the Anadosis or up-rising of the Earth Goddess, Pandora, is a favourite subject. ${ }^{3}$ As regards the cultus, the advance towards anthropomorphism is marked by the belief current in Bengal that at the first burst of the rains in June-July, Mother Earth, in order to prepare herself for her fertilizing work, is supposed to menstruate. During this time there is an entire cessation from all ploughing, sowing, and other farm work; widows abstain from eating rice; next comes the rite of purification, when a stone representing the goddess is fixed erect in the ground, its top is smeared with vermilion, a survival of a blood sacrifice, the housewife bathes it with turmeric water, a betelnut is placed on a piece of wood close by, the stone is bedecked with flowers, and offerings of milk and flowers are made. ${ }^{3}$ A similar rite of purification, under Brăhman auspices, is performed in the case of the goddess Bhãgavatĩ, "the Venerable, Divine One," at her temple in Travancore, after her menstruation, which is supposed to take place ejght or ten times during the year. ${ }^{3}$

'B. Ziegenbalg, Genealo,gy of the ,iouth Indian Ciats, 137; A. Grinwedel, Simlihist Art in londia, 98 et seqg. ; Miss J. E. Ilarrison, Protigomenn to the Study of Cireek Neligion, 276 at segy. ; Id. Mythology and Monumen's of States, iii. "Sir] $17,25,27,55,216$.

[Sir] E. Gain, Census Report, Bengal, rgot, i. 189.

'V. Nagam Aiya, 7 ravancore State Manikal, ji. 89 at seq. 


\section{8 .The Cults of the Mother Goddesses in India.}

Again, the Earth Goddess, being the primary source of that Mana which fertilizes men and animals, and brings the fruits of the earth to harvest, naturally becomes periodically exhausted, and needs repose to recruit her energies. In Malabar in January.February the field work is over, and Mother Earth rests during the hot weather until the first shower of rain, when she revives and undergoes the natural function of women just described. ${ }^{1}$ This periodical rest of the goddess, to which further reference will be made later on, is observed throughout the country in various ways. In the Panjāb she sleeps on seven or eight days in each month, and on these days ploughing and sowing are tabu, with this concession that if inadvertently work has started on these days, it may be finished. ${ }^{2}$ In the Deccan, after the Naurătri, or Nine Nights' feast of the goddess in September-October, her temple is closed from the sacred I Ith day of the month until the full-moon day, while the goddess rests and refreshes herself after the liberal distribution of Mana to her worshippers during her festival. ${ }^{9}$ In the Deccan many people make a vow to live during the rest of the goddess in the country north of the river Godä. vari, this being regarded as the southern boundary, marking off Hindostan from the non-Aryan tribes of the south."

Naturally after her periodical rest the Earth Mother needs to be aroused. This rite goes back to Vedic times, when, at the Mahavrata festival, maidens carrying water pitchers used to dance round a fire and sing: "The cows smell pleasantly: here is sweet drink ! the cows are

'L. K. Anantha Krishna Iyer, The Cochin Tribes and Castes, ii. 78.

"North Indian Notes and Queries, ii. 172; Rnujib N'otes and Queries, ii. 205 .

- Bombay Gasetheer, xx. 444.

M. M. Underhill, 7he Indian Year, 14. "The I'hrygians, according to I'lutarch, believed that their god slept in winter and waked in stmmer, and accordingly they celehrated with Bacchic rites the beginning and end of this period of rest" (Sir J. G. Frazer, The Golden Bough, 3 rd ed. Allawis, Altis, Osiris, ii. 4I). 
The Cults of the Mother Goddesses in India. 289

mothers of butter : sweet drink! the cows we here bathe: sweet drink!" As they danced they struck their right thighs with their right hands-probably with the intention of expelling evil influences and promoting fertility: or they used to beat the earth with their right feet, and danced, following the course of the sun. ${ }^{1}$ At the sowing rite of the Garos the priest invokes Rokimē, "Mother of rice," and striking the earth with a chopper-handle reminds the goddess that certain flowers have blossomed in the jungle, which is a sign that it is now time to sow the rice of which she is the Mother. With this beating of the ground with a chopper-handle we may compare the Greek vase painting interpreted by Miss J. E. Harrison, where a Satyr is beating the ground to wake the Earth Mother, Pandora. ${ }^{3}$ At the Orãon Jeth Jātra festival, according to Colonel Dalton," the girls used to pat the Earth to make her fruitful. Later enquiries, however, show that it is the young men who carry fans made of wild date leaves, or yak tails, which they Wave over the Earth as if coaxing her to bear abundant crops. Mr. Sarat Chandra Roy points out that, in Orãon belief, this is the function of males, not of women. Hence women are not allowed to plough or sow, but they may transplant the rice seedlings after they have been grown by the men, because it is the business of women to tend them, as they do in the case of their own babies. ${ }^{5}$ The first act done when a male child is born among the Nãyars of Malabar is to beat the Earth with a coconut leaf, or, in the case of a girl, to grind some turmeric in a mortar. This

'A. B. Keith, "The Vedic Mahatvata," Transactions Third Inlernational Congress for the History of Religion, ii. 55.

A. Playfair, The Garos, 93.

"Journal llellenic Socialy, xx. (1900), to6 ef seq, xxi. (1901), 6; L. K. Farnell, Culls of the Greck States, iii. 26, I12, 205.

- Descriptive Ethnology of Bengal, 198.

"Sarat Chandra Roy, op. cil. 320. For a duubtful example of thrashing the Farth to make her fruilful from New Caledonia, see E. S. Hartland, Primitive Paterwity, i. II note. 


\section{The Cults of the Mother Goddesses in India.}

is done, it is said, with the object of removing the child's fear, and part of the puberty rites of the Paraiyans is for the mother to strike the ground behind her son with a rice-pestle. ${ }^{1}$ The meaning of these rites is obscure: possibly they may be fertility observances intended to arouse the Earth Mother to strengthen the boy.

The great gods, Vishnu and others, also sleep from June-July till October-November, that is to say, during the rainy season when field work is slack. The same considerations, based on the cessation of work during the rains, account for the annual Buddhist Retreat (varsika, vassa, vassavasa), during which the monks ceased to make their usual visits to their disciples. The similar Retreat of the Jains (pajjusana, pachusan) should be held when the rainy season is well advanced, a time when ordinary work is interrupted, and there is danger of destruction of life, animal and vegetable, which is then abundant. ${ }^{3}$

Similar animistic beliefs regarding the personification of Mother Earth and the danger of destroying the life which she fosters account for the prejudice against agriculture which prevails among some tribes, castes, or religious orders. The Laws of Manu, the official manual of Brahmanical social observances, direct that a Brăhman or a Kshatriya shall carefully avoid agriculture, "which causes injury to many beings and depends on others. Some declare that agriculture is something excellent, but that means of subsistence is blamed by the virtuous : for the wooden implement with iron point injures the Earth and the beings living in the Earth." " A religious sanction was thus given to the prejudice against agriculture, work which

'E. Thurston, Castes and Tribes of Sowthern India, v. 344, vi. 93.

"II. Kern, Mlanual of Indian Buddhism, so et seq.; C. J. F. S. F.,rbes, British Burma and its l'eople, 170; Shway $\mathrm{Y}$ e, the liurman, i. 263; L. A. Waddell, The Butdhism of 7hibet, 223 at sey.

- Mru. M. Stevenson, Ilastings: Encycloraedia of hidigion and Lithics, v. 675.

- Manu, Lawes, x. 84, 85; cf. Sir J. G. Frazer, Golden Bough, ird ed. Adonis, Altis, Osiris, i. 88 et seqy. 
was not suited to the Aryan priest and warrior. Hence they were in the habit of making it over to the autochthonous peoples, and many Rajputs and Brähmans at the present day will not handle the plough. Buddhists adopted the same rule on account of the danger likely to be caused to animal or vegetable life by ploughing: but they were forced to make an ingenious compromise, to wit, that a man should not till land for his own advantage, but that to do so for the benefit of the Buddhist Sanga, or com. munity, was not opposed to the teaching of the master. ${ }^{1}$ In the same way, the Jains are particularly careful not to destroy all animal and some vegetable life. They object to build a house, to till a field, to eat earth-grown vegetables, like potatoes, beet, or onions, but they will eat oranges or mangoes, which, being in the air, do not form a refuge for life (jiva): a pious member of the sect must never sell artificial manure, as it is sometimes made from the bones of dead animals, or take a contract for building houses or digging wells, because an insect may be destroyed in the course of the work: for the same reason the trade of a blacksmith is tabu among them. ${ }^{2}$ Hence also arose the custom of having the first ploughing done by one of the menial tribes, like the Kurumbas of southern India, who risked the danger which his masters were afraid to face. ${ }^{3}$ The King, being sacrosanct, was also required to do the sacred ploughing."

\footnotetext{
'I.tsing, A Alecord of the Buddhist Keligion as practised in India and the Malay Archipelago, trans. J. Takakusu, 6r.

"Mrs. M. Stevenson, The Mtcart of Jainism, 115, 138, 141, 214, 223. "The Bhatian, traders in Cutch, will not deal in vegetables or root crops" (Bombay Garetteer, v. 54).

"Thurston, op. cit, iv. 168 ; F. Metz, The Tribes inhabitingr the Neilghery" Hills, 116 ; Folk-Lore, iv, 215 .

"Sir J. Bowring, The Kingrom and People of Siam, i. 158; H. C. Warren, Budhthism in Transhations, 54; The Jutakn, Cambridge tranm. iv. 104; [Sir] J. G. Scott, J. P. Hardiman, Gasetteer of Upper burma and the Shan Sintes, part $t$, pol. i. 52, vol. ii. Iol; Sir J. G, Frazer, Pausanias, ii. 172, 4\$9, 314 ; The Colden Bough, 3rd ed. The Dying Cod, 149 ef seq.
} 


\section{The Cults of the Mother Goddesses in India.}

It is needless to discuss the many beliefs implying that Mother Earth in India is regarded as the prime source of Mana. One rite, specially connected with fertility, deserves notice. All over the country, as part of the marriage ceremony, the women of the family go to the village clay-pit, and bring from thence the Matmangară, or "lucky earth," which is generally used in building the fireplace on which the materials of the wedding feast are cooked." In southern India this "lucky earth" is brought from an anthill, because ants which swarm in numbers are a type of fertility. ${ }^{2}$ Other circumstances enhance the luck of such earth. In Poona seven kinds of "lucky earth" are brought-from a Kings' palace gate, from a hill, from under the foot of an elephant or of a horse, from a place where four roads meet, from a cowshed, and from under the sacred väla tree (andropogon muricatum)..$^{3}$ At a Rajjput wedding in Bljāpur, a relative of the bridegroom goes to the bank of a river or a tank and worships Mother.Earth by pouring water on her surface : he daubs the place with sandalwood paste, and throws rice and flowers on it: then he loosens a clod with a pickaxe and brings it to the marriage booth." In the Telugu country, the earth, known as "Golden produce," is brought from a tank with much ceremony by five women-a lucky number-who are accompanied by a band of music, and they have a cloth held over them as a canopy, probably to protect them from the Evil Eye and from the attacks of malignant spirits i it is added to a pile of earth, decorated with coloured pig. ments, which is raised in the marriage shed, and beside it the bride and bridegroom sit ; the pile is not removed, but left untouched until wind and rain destroy it. ${ }^{5}$ At a

$2 \mathrm{~W}$. Crooke, of. cit. i, 27.

"Thurston, of. cit. vi. 355. "The anthill, being sacred, is often used as " shrine of the village goddess" (Bishop Whitehead, op. cit. 79).

-Bombay Gazetsoer, xviii. part I, 141 note.

Ilid. xxiil. 159.

"J. A. Padfield, The Hundu at Howe, 144. 


\section{The Cults of the Mother Goddesses in India. 293}

Brăhman wedding in Gujarăt, the earth is used for making the altars used in the rite known as Grihasanti, or "planetsoothing," by which the dangerous influence of some planet, which would mar the success of the marriage, is removed. ${ }^{1}$ The intention of these ceremonies is probably to convey to the married pair the fertilizing Mana of Mother Earth.

When Mother Earth is thus regarded by the Hindus as a living creature they unconsciously confirm the latest conclusions of science. The well-known French agronomist, M. G. Dumont, has recently shown that the Earth is a living organism, and that the earthy elements are merely the skeleton which holds together its respiratory, digestive and muscular portions. Respiration is the interchange of gases, the digestive apparatus the interspaces supplying nutritive liquids to the plant roots, the muscular action the contractions which excite coagulation, and which are due to the colloidal membranes covering the earth particles. Folklore, as is often the case, is thus justified by the con. clusions of science.

Thus far we have been considering Mother Earth in her benign, kindly aspects, as the maintainer and giver of fertility to men, animals, and plants, the patron goddess of agriculture, in which respects she is the counterpart of the Hellenic and other deities of the West. In this aspect she is closely connected with the cult of trees, which force their roots into her bosom, and draw support from her, while by their branches they link her with the spirits of the air. So in Greece, Europa, "the broad-faced," the equivalent of the Hindu Prithivi, probably a Cretan. Bocotian form of the Earth Goddess, was worshipped at Gortyna in a sacred tree." In India, as we have seen, she is associated with the communal tree, the planting of which is the first act in the foundation of a new village. But, at the same time, the tree acts as a prophylactic, because it

1 Bosmbay Gasettces, ix, part 1, 42 at seq.

A. B. Cook, Zews, i. 537 ; Farnell, op. cir, ii, 14, 30. 
gives shelter to all sorts of malevolent spirits which beset the inhabitants. A curious instance of this belief comes from Poona. When his parents murdered the Marätha Peshwa, Nārāyanrāv in 1772 , his successor, after two intervening members of the house, Bãjirãv, who believed himself to be haunted by Nārãyanrãv's ghost, planted several hundred thousand mango trees round the city to afford a shelter to the angry spirit. ${ }^{1}$ In connexion with the fertility cult, the value of the tree is improved if it be ceremonially wedded to another tree.

Near every village of the Pãvräs, a forest tribe in Khãn. desh, is a sacred tree, round which, before harvest, the villagers prostrate themselves before the rising Sun, offer grain, and sacrifice goats and flowers. This tree god, known as Bãvä, or " Father," Kumbã, has a consort, Rānl, "Queen," Kājhal, who lives in another sacred tree not far off." Hence, the Mother Goddess, like Sijū, the Kächāri god, of ten lives in a tree. The Rãjput legend tells that their patron goddess Āsāpūrnã, " Fulfiller of desires," appeared out of a tree to protect the princess Surabhi, when, a fugitive, she lay almost at the point of death under its shade. $^{3}$

Particularly among races who bury their dead, the Earth Mother is apt to assume a chthonic and malignant character. In India, as in Greece, the snake forms the link between the benign spirits, ancestral or other, and the malevolent earth genii. In Bundelkhand certain snakes known as BhiaränI, a word interpreted to mean, "Dwellers in the Earth," are regarded as forms of Devi, the Mother Goddess : coconuts are offered to them by priests drawn from the menial castes, while a Brāhman generally lives close by and receives a share of the offerings. ${ }^{5}$ In the

1 Bombay Gaetleer, xviii. part 1, 293.

Hoid. xii. 97.

- Playfair, op. rit. 18 ; J. Tod, Ammals of Kajasthan, ed. 1919, Hii. 1461.

- Miss J. E. IIarrison, Jowrnal Hellewic Society, xix. (1899), 213.

- C. E. Luard, Census Report, Central India, I901, i. 75 . 
Chambã State, on the borders of Kashmir, the Devis are goddesses who have power to cure diseases in man and beast ; they are not, like the Nãgs, or true serpent deities, associated with springs, but it is common to find Nāg and Devi temples side by side, and similar attributes are assigned to both. ${ }^{1}$ On the other hand, these Devis, as promoters of fertility, are worshipped in Bashahr in the forms of little girls. ${ }^{2}$

This chthonic aspect of the Mother Goddess may be illustrated by the custom of burying in the earth portions of the victims dedicated to her. When a careful Athenian went to gather a certain medicinal root, he used to place in the hole a honeyed cake as an offering to Gaia, the Earth Mother. ${ }^{8}$ For the same reason, at the Thesmophoria festival, live pigs were thrown into the underground sanctuaries of the goddess." The pig, possibly on account of its habit of rooting up the ground to obtain food, was the sacred animal of Demeter and Kore. ${ }^{5}$ In southern India, at the worship of the Grãmadevatã, or village goddess, a buffalo, which is also possibly on account of its black colour and brutish appearance a chthonic animal, the beast upon which Yama, god of death, rides, is buried in a pit close to the boundary stone which is occupied by the goddess. In the same part of the country we find the custom of burying a live pig in the village street, where the cattle pass in and out on their way from and to the fields, probably as a prophylactic propitiation of the Earth Mother : in some cases the pig is buried up to the neck

'H. A. Rose, Gloswary of the Tribes and Castes of the Punjab awd the North. Hestem Frontier Province, i. 331.

Tbial, i. 479.

Farmell, op. cit, iii. I5.

1 Jbill. iii. 89 at seqg.

-Miss J. E. ILarrison, Prolegromena to the Study of Creck Religion, 122; J. C. Lawson, Modern Grek Folklore and Ancient Greek N'rligion, 87; Sir J. Frazer, The Golden Bough, 3rd ed. Spirits of the Corn and the Wild, ii. i6 el sequ.

- Bishop II. Whitehead, op. cit. 108, $111,113$. 


\section{The Cults of the Mother Godilesses in India.}

at the entrance of the village, and the cattle are driven over it until it is trampled to death, while rice stained with the blood of a sacrificed lamb is scattered over the herd. ${ }^{1}$ The Goālas, herdsmen in northern India, turn a pig loose amidst a herd of buffalos, which are encouraged to gore it to death. ${ }^{2}$

It has been assumed by some scholars, as has already been stated, that the cults of the Mother goddesses, benevolent or malignant, have all been derived from that of Mother Earth, in these differing, but complementary manifestations. This theory has been disputed by orthodox Brăhman writers, like Pandit Harikishan Kaul. ${ }^{8} \mathrm{He}$, by a method characteristic of Hindus discussing their own religion, traces all these goddess cults back to the Vedas, maintaining that there is but one original Mother Goddess, that the later forms are developments of her worship, and denying that these have any connexion with Mother Earth. "The personification of the powers of the Creator, the Preserver, and the Destroyer being once established, the identification of any one of them with important, uncommon, or uncontrollable phenomena is an easy matter." But we have already seen that in the Vedas the goddesses hold a subordinate position, and this theory ignores the distinctively local character of the worship. It is not from any original Vedic goddess that the modern worshipper of great personalities, like Tulja Bhavañ in the Nizam's Dominion, Ambā Bhavānl of Mount Abu in Rajputana, Hinglăj Mătă in Balochistan, or the mighty Kāli of Calcutta, traces his devotion. The process by which these great personalities acquired their present reputation was clearly because, for some reason, the local cult from which they were derived gained the credit of wonder-working beyond the small

${ }^{1}$ Bishop H. Whitehead, op. cit. 52, 58, 59 .

[Sir] II. Risley, Tribes and Castes of Bengal, i. 290; Folk-Love, xxviii. 154 et seyg.

"Consus Report, Panjab, 1911, i. 114 at seqq. 
circle of their original worshippers. In other words, the conception of a single great goddess,-Devi, Durgã, Kăll, is later in order of time than the local cult out of which it originated.

The facts already stated lead to the inevitable conclusion that many of the Mother goddesses have been developed from the Grảmadevatã, or village goddesses, many of whom owe their origin to the cult of Mother Earth. The benignant and chthonic, or malignant, manifestations of this Earth goddess account for the two distinct types which we find among the Mothers as a class. The localisation of function in the case of the village goddesses opens the way for the specialisation of the Mothers, many of whom ultimately come to be regarded as responsible for distinct spheres of activity; various classes of disease, for instance, being made over to distinct deitics. But this is a later development, the Mothers, as well as the other deities of Hinduism, being in their most primitive types deitics "of all work." This does not affect the theological so much as the practical aspect-the cultus. "The really important question," as Robertson Smith puts it, "is not what a god has power to do, but whether I can get him to do it for me, and this depends upon the relation in which he stands to me." I

At the same time, in dealing with a complex polytheism like that of Hinduism, it is rash to assume a single origin for a group of deities, with infinitely varied legends of origin and cult ritual. And there are types which cannot readily be derived from the Earth Mother.

In the first place, we have the group of the Forest Mothers. While the village Mothers, as representing the agricultural stage, may be propitiated with animal sacrifice, there is no evidence that the dweller in the jungle offers the produce of the chase, a boar or a stag, to his Mother goddess. The common method of propitiating them is for each passer-by

+ The Religion of the Semules, and ed. 83. 


\section{The Cults of the Mother Goddesses in India.}

to add a stick or a stone to the rude heap which marks the abiding-place of the deity. In the Vedas large trees, called Vanaspati, are addressed as deities, and the forest, as a whole, appears as a goddess under the name of Aranyannt, called "Mother of beasts," abounding in food without tillage, in whose dark solitudes various uncanny sounds arc weirdly described. ${ }^{1}$ Aranyāni has now passed out of popular knowledge, but Vanaspati, in the form of Ban. sapti Mā, "Mistress of the wood," is, in Northern India, propitiated by flinging a stone or branch on her cairn, either as a mode of keeping the spirit under control, ${ }^{2}$ or as a tribute to, or recognition of, the dreaded deity who abides in the dark places of the jungle. But she is developing into a goddess of the agricultural type, because village herdsmen who graze their herds in the jungle offer to her a cock, a goat, or a young pig, with a prayer that she will protect the cattle from tigers. ${ }^{3}$ In the Central Provinces the cult of Banjäri Deo, possibly a deified member of the Banjāra carrier tribe who used to drive their cattle along the jungle paths, is so imperfectly organised that the deity who dwells in a cairn to which every one adds a stone, may be male or female. ${ }^{4}$ The Paniyans, a forest tribe in Madras, worship a femalc, Kad Bhägavati, or a sexless deity called Kuli, who dwells in a stone or cairn. Major Tremearne ${ }^{\circ}$ suggests, in the case of Hausa deities, that this uncertainty about sex may depend upon a change from polyandry to polygamy, or upon the relations of the goddess with her consort; but this does not scem to apply to Indian deities of this class, who are so vaguely conceived that the question of sex becomes immaterial. Goddesses

'A, A. Macdonell, Vatic Nythology, 154. "Vanaspati, 'Lord of the forest,' in the Vedas primarily denotes tree" (Jd. and A. B. Keith, Vedic Index, ii. 24I).

"Sir J. G. Trazer, The Golden Bough, 3rd ed. The Scafegunt, is at seqg.

Crooke, of cit, i. 115.

A. E. Nelson, Gazetleer of Rilospur District, i. 74.

SThurston, op. cit. vi. 62 .

"The Ban of the Bori, 418 . 


\section{The Culls of the Mother Goddesses in India. 299.}

of this type do not appear to be connected with the cult of Mother Earth because their worshippers are in the pre-agricultural stage.

Secondly, there is a type of Mothers who are generally acknowledged to be of human origin. Many of the southern Mothers fall into this category, such as Gangammā, sometime regarded as a form of the divine river Ganges, who is also said to have been the daughter of a Brahman, and Pangammā, one of three sisters who made a famous tank.' This type of Mother is particularly common in Gujarăt in the shape of the deified spirits of women of the Charan tribe, people who, in the old days of anarchy, used to take charge of convoys of treasure, and were ready to give their lives in its defence. The murderer of such guardians was belicved to be haunted by the angry spirits of his victims, and even now, though their traditional occupation has ceased, Charan women are supposed to possess supernatural powers, and are addressed as "Mother," or "Goddess Mother." Many of the most famous Mother Goddesses in Gujarât belong to this class."

Thirdly, we must not dismiss the possibility that some Mothers may be simply animistic or pre-animistic spirits, impersonation of the awe and terror with which people of the lower culture regard anything quaint or abnormal. Possibly some of the Jungle Mothers may be included in this class.

But the general class of Mothers is so vague, " figures as melting and shifting as the clouds of sunset "- -so Andrew Lang described the Vedic gods ${ }^{3}$-that the study of their origin and relations is difficult. In their earliest forms they are purely local, regarded as having no relation to the

'A. F. Cox, A. II. Stuart, Manseal of the North Arcot District, i. 186. See other instances in Bishop Whitehead, op, cit, 26, 32, 73, 118, 123.

'A. K. Forbes, Ras Mala, and ed. $426 \mathrm{f}$; Bombay Gazatreor, v. 76, vil.

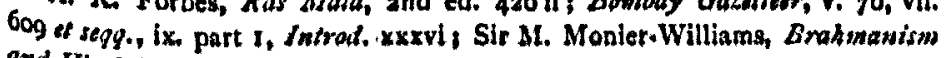
and Ninduism, qth ed. 223 at seg.

alyth, Ritual, and Religion, i. $16 \mathrm{~s}$. 


\section{The Cults of the Mother Goddesses in India.}

world as a whole. But when they are adopted by Hinduism they become great deities whose sphere of action is unlimited. These two conceptions, as .well as their kindly and malevolent manifestations everywhere interminglc, and cannot readily be distinguished. As Bishop Whitehead remarks, to the peasant of South India they are neither exclusively evil spirits nor unmixed benefactors : they are of uncertain temper and very human in their liability to take offence. ${ }^{1}$ It might have been expected that much help would be derived from their cult titles, a study of which has been so fruitful in explaining the Hellenic pantheon. But the most common epithets are vague-Mātã or Mã, "Mother," Devi, "The Divine One," or, vaguer still they are known as Gråmadevatã, "Village Godlings," or even in north India as Dih, "The Village." The same goddess may be, on her kindly side, Lakshmi or Sri, goddess of good fortune, now consort of Vishnu :" Lokamåtã, "World Mother" ; Āsãpưrnã, "Fulfiller of Desires" ; Annapũrnă, kapropópos, "She that fills men with grain," or Săkambhari, "Nourisher of Herbs," the counterpart of Demeter Chloe, goddess of young corn and other vegetation. On the other side she may be Durga in her varied forms, or Kāli, " The Black One," Demeter the Black, whom Mr. R. V. Russell calls a deified tigress.' Some titles are purely euphemistical, based on the theory that by the use of a flattering divine name, the worshipper, if he has really learnt it, may coerce the deity to grant his desires.

Many names are pure inventions of the Brăhman officiants, many, and perhaps the most popular mark tho local character of the cult.

1 op. cit. 25.

" "Iler name appears as early as the Satapahha Brahmana (A. A. Macdonell, A. B. Keith, Vedic (ndex). Rhys Davids, Buddhise India, 217 al seg. "She is represented in Buddhist culptures seated on a lotus while two elepbants pour water over her" (A. Grunwedel, Buldhist Art in Iwdia, 39). 
We have seen that in the Vedas, as well as in Babylonia, the cult of goddesses is subordinate to that of gods. The Vedic Hindus were in the agricultural stage, but they had only recently emerged from the pastoral. And much of the work of tilling the soil was probably done by the aboriginat races whom the Aryans found in occupation. ${ }^{1}$ This con. tempt for agriculture has descended to some modern Råjputs and Brāhmans. We have, therefore, to look for the origins of Mother worship to these indigenous people which we may call Dravidian, or Mon-khmer.

It secms dangerous to press too far in theory that the worship of the Mothers depends upon the leading part played by women in agriculture in many primitive societies, and among some of the present Indian tribes and castes. Nor docs it seem to be connected with Mother Right. In India, as is the case elsewhere, agricultural ceremonies and the culture of the local gods are often entrusted to women because they are more emotional, believed to be in closer touch with the spirit world, endowed with a stronger fertility Mana than that possessed by men. But the appointment of women as regular priestesses seems to be uncommon, Bishop Whitehead mentioning an exceptional case in the worship of the Mother goddess Nakulamma." There does not appear to be any sound evidence that the cults of the Mothers in India were, to any special extent, dependent upon the cooperation of women in agriculture, a coopcration which, as we have seen in the case of a primitive tribe like the Orãons; is carefully restricted. It may be

\footnotetext{
'B. II. Baden-Powell, The Indian Village Community, 188. The facts are collected in a convenient shape by $\mathrm{P}$. T. Srinivas Iyengar, Lifo in Ancisus India in the Age of the Mantras, 23 at seqg. The viewa of Baden. Powell are criticised by Macdoncll-Keith, Vedic Index, 1. 182, it. 173, 254, 333 at stq." Who describe the importance of agriculture in Vedic times.

F. B. Jevons, Introduction to the Hiatory of Religion, tat ed. 239 of segg.; Miss J. E. Ilarrison, Arolegomena to the Siudy of Greek Ridigion, 27a; and compare l'rofessor Gilbert Mlurray, Four Stages in Greek Riligion, 78.

- Op. cil. 63.
} 


\section{The Cults of the Mother Goddesses in India.}

suggested that it was as agents of fertility in general that the Mothers were deified. These cults, in their more ecstatic or hysterical form, prevail chiefly among the Dravidians of the south, where they are connected with practices like devil-dancing, spirit possession and the like, which are less common among the more sober and less excitable races of northern India. In that part of the country it is only in places outside Āryãvarta, the original Holy Land in the south-western Panjab, that the more brutal forms of animal sacrifice and ecstatic rites are found, as at the shrine of Kăli in Calcutta, Kãmåkhyã in Assam, Devi Pãtan in northern Oudh, and in Nepāl.1

The explanation, again, of Bishop Whitehead, ${ }^{2}$ that the cult was based on Totemism, does not seem to be convincing. So far as we are acquainted with the principles of Totemism in India it seems to have affected social institutions much more than religious beliefs or ritual.

When Mother worship is taken over by Brahmanism it exhibits those naive attempts at organisation and the otiose symbolism and ritual which are characteristic of that form of belief. The Mothers are usually classed in well-defined groups, sometimes of seven, cight, nine or sixteen." Their powers and activities in special fields are more carefully discriminated. In the standard form of ritual current in the lower Himallaya they are worshipped in connexion with Ganesa, lord of luck and controller of enterprises, as a preface to the other rites. The cclebrant takes a plank, cleanses it with rice flour, and on its surface draws seven figures representing the Mothers, with Ganesa on the right, and on the left a representation of the Moon. He then makes a brush out of five or six stalks of the sacred düb (cynodon dactylon) grass, and dipping it in cowdung,

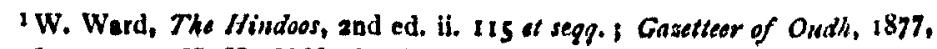
i. $3^{67}$ at segq. i II. II. Oldfield, Sketchas from Nefal, ii $293 \mathrm{et}$ seq.

Op, cit, 146 at seqg.

-Oppert, op. cit. 447 at seqq. ; Ziegenbalg, op. cit, 36, t33. 
anoints with it each of the Mothers, recites verses of praise in their honour, pours a libation of butter and sugar over the figures, waves a lamp before them, and offers flowers. The rite ends with the recital of a hymn in their honour, the celebrant receives his fee, and in return places a flower from the offering on the head of the person at whose expense the ceremony has been performed. ${ }^{1}$ In another form of the ritual the Mothers are symbolised by a series of earthen pots in which they are supposed to dwell, reared in piles, and placed in the marriage shed as dispensers of fertility. In southern India we meet a special Pot goddess, and at the Durga Puja festival in Bengal the installation of the goddess in a pot is a prominent part of the rites. ${ }^{3}$

It is at present impossible to give even a summary sketch of the cultus of the Mothers. Much has been done in southern India by workers like Bishop Whitehead and Mr. F. J. Richards : but much further enquiry is necessary before this interesting phase of Indian popular religion is thoroughly explored. The personality of these deities is still imperfectly known. In many places the goddess is at once maid and mother, like Demeter and Kore, and year by year, as Hera did by bathing in the Canathus spring, she renews her virginity, only to lose it again when she performs a ritual marriage at the sowing or harvest festival." In the case of Demeter and Kore it has been assumed that the former represents the true Earth goddess, her daughter being the impersonation of the young earth and vegetation in spring. ${ }^{5}$ This is probably true in the case of the Hellenic goddesses, but it may be suggested that in India the personification of mother and virgin is based on the perio-

'Atkingon, op. cit. ii. $83+$ at seq. For a full account of the rites at the temple of the famous Baroda Mother goddess, Bechraji, see Bombay Gasetleer, vii. 609 at selg.

ISee a photograph in Thurston, op. cit. vi. Ig.

"Oppert, op. cit. go3, I'ratape Chandra Ghosha, The Durga Puja, $3^{2}$ et sefg.

'Pnusanias, ii. 38, 2. "Farnell, op, cil. iii. II6. 


\section{The Cults of the Mother Goddesses in India.}

dical renewal and loss of virginity after a ritual marriage. At any rate, the cult of the Virgins side by side with that of the Mothers is not uncommon. In southern India seven Virgins are worshipped, and in the Panjab some rugged rocks are called Kunwãri, or the Virgins, to commemorate, it is said, a party of maidens who were killed to save their honour, and deified after death. ${ }^{1}$ We also meet, from the Vedic age down to modern times, the cult of pairs of twins, often brother and sister. ${ }^{2}$

As we have seen, the Mother, exhausted by her labours, needs periodical rest to renew her strength. The same result is also provided by two methods : the sacred marriage, the iepós yámos of Greek ritual, and by blood sacrifice.

As regards the sacred marriage-we must be on our guard in accepting the numerous cases in which the Mother is regarded as the consort of some deity, unless we can actually prove a ritualistic marriage. The Brahmanical craze for uniformity usually leads them to class the divine pair as wife and her consort. Among the Dravidians, who are less exposed to Brăhman influence, we have many cases of the sacred marriage. The Malayalis annually marry their god Sevarãyan to the goddess who is the presiding deity of the Kävërl river." Though there is no direct evidence of a ritual marriage, some goddesses are closely connected with a male, as in the case of Orasandiamma and Samalammã, tutelary goddesses of the Vãda fishermen, associated, the former with Rămasondi, who is her brother, and the latter, curiously enough, with the image of a Bengali Babu on horseback. In many parts of Madras, Poturăzũ is at once husband, brother, and

'Bishop Whitehead, of, cit. 101; Rose, of, cit, i. 13 I.

E. W. Ilopkins, The Religions of India, 83 note. "Incest was recognised in Vedic times, as appears from the legend of the marriage of Yama and Yamt, brother and sister" (A. A. Macilonell, A. B. Keilb, Vedic Index, i. 397).

s Thurston, op. cit. iv. 415 tt seg\%.

- Jbid. vii. 26 I et seq., 264. 


\section{The Cults of the Mother Goddesses in India. 305}

attendant of the goddess Dayamavvā.' In Bengal, several gods and goddesses of the Tipåra tribe are marricd to each other; in the Rajshahi District the Sun is married to Chhatmātã, the Sixth Day Mother, so called because this is the date of her festival : Koilā Mătā, a Mother goddess of Bihār, is sometimes conceived to be a male, Koilā Bābā, and when a well is being excavated a male image of wood is made and marricd to that of the goddess : Hudum Deo, who is now beginning to be identified with the Vedic Indra, is worshipped by the Rajjbansis of Dinājpur in androgynous form-two figures made of clay or cowdung representing, the one a male, the other a female: Ghanta Karana is consort of Sitala, the small-pox goddess." The classical case from Bengal is the marriage by the Orãons of the Earth with the Sun, with formal rites, in spring when the Säl tree blossoms. In Chota Naggpur we have one of the best instances in the case of the Kharwar goddess, Müchak Ràni, which I have elsewhere published." Among the Kandhs, Bura Penna, god of light, has, as his consort, Tàrã Pennu, the Earth goddess. ${ }^{\circ}$ In Contral India, Kam. paravara, a god of the Bhil tribe, is married to the goddess Kajal, and at the Akhtij festival, at the opening of the farming season at the close of the annual rains, the Bhrls marry, in the form of two wooden dolls, the deities who control the rains, and as soon as the rains come, they throw these images into a stream. ${ }^{6}$

When these aboriginal cults are taken over by the Brăhmans, the rite of the sacred marriage becomes rapidly

\footnotetext{
'Journal Anthropological Saciely, Bombay, ii. 269, vil. 637, 642; F. R. Hemingway, Gasetleer Godidvari District, l. 4\$, Bishop Whitehead, op. cit. 18.

'[Sir] E. Gait, Consus Report, Bengal, 1901, i. 187, 188, 190, 191, 193.

- Ibia. 189 ; E. T. Dalton, Descriptive Ethnology of Bengal, 261 ; P. Dehon, Memoirs Asiatic Society of Bengal, i. 145.

- Popular Roligion and Folklore of Northern India, and ed. ii. 322 et segg.

'S, C. Macpherson, Memorials of Service in India, 84 .

C. E. Luard, Ethugraphical Survey, Central India, Art. Bhil, p. 29.
} 


\section{The Cults of the Mother Goddesses in India.}

developed. Mr. F. J. Richards, who has made a special study of Dravidian religious beliefs, informs me that, in his opinion, most cases of the sacred marriage in Southern India are due to Brăhman influence. Thus, Minādchi, "Fish Rule," the Tanjore goddess, a true Dravidian deity, is now married to Siva. ${ }^{1}$ Some of the goddesses of the Meithei tribe are married, but this, too, seems to be a Brăhman rite. ${ }^{2}$ The goddess Tulasi, the impersonation of the sacred basil plant, is married annually in Kảthiāwär to Vishnu, or to his embodiment in the sacred ammonite, the Salagräma. ${ }^{3}$ The same goddess in the Bhandāra District of the Central Provinces is married to the Sallagrăma : sugar-cane, onions, garlic, and wild plums, from which the people abstained during her four months' slcep, are offered to her and then eaten." In the Bijāpur District the goddess Parrvati is annually married to Sangameswar, the presiding dcity of the sacred river junction. ${ }^{5}$ We reach a lower animistic stage in the marriage of the goddess Dyamavva in the Dharwar District to the holy sacrificial buffalo, which represents her husband, a man of the menial Mahăr caste. In the northern plains we meet with few cases of this kind, or they are obscured by elaborate Brahmanical rites, but in the Himalaya, at the Nandashtami festival held in the month Bhảdon during the rainy season, the hill Mother Nandaz or ParvatI is solemnly wedded to Siva.? The rites of the sacred marriage form a favourite

Thurston, op. cit, iii. 85 ; Mradras Mlanual of Administration, iii. 499.

'T. C. llodson, The Mlatheis, 97 et seq.

${ }^{3}$ Bombay Gasolteor, vii. 527, viii. 667.

1 R. V. Russell, Gasettoer Bhasudira District, i. 49.

sombay Gasetteer, xxiil. 676.

- Jbid. xxii. 81o. For this sacred buffalo, called Devara Potú, see Bishop Whitchear, of, cit. 88.

'E. T. Atkinson, op. cit. li. 792. For a full account of the sacred mairinge, see Sir J. G. Frazer, The Giolden Bowgh, 3rd ed. The Magric Art, ii. 120 et segg. 


\section{The Cults of the Mother Goddesses in India. 307}

subject of Indian art : for instance, it is represented, in the case of Siva and Parvati in the Caves of Elephanta."

The Mana of the Mothers is also reinforced or restored by blood sacrifice, especially of a male victim, whose shivering, stimulated by pouring water on its back, indicates that it is possessed by the deity, when it is slain at once by a single stroke, in order to prevent the Mana from being dispersed and lost. ${ }^{2}$ But it is still believed that unless the victim is subjected to torture or meets with a tedious death, the state of tension requisite for the accumulation and bestowal of the Mana will not be attained. Hence we find that the animal is ill-treated, beaten, crushed, or trampled to death, preventing the careless effusion of blood which is the prime vehicle of the Mana. Such barbarities are a scandal in the popular ritual.

It is impossible to discuss in detail the question whether this type of sacrifice is communal or not; the theory that it corresponds to the Semitic type of sacrifice is supported by Bishop Whitehead, but his remarks do not carry complete conviction." There are certainly points of resem. blance:-the meat is cooked by the men of the menial castes who perform the rite, and it is eaten there and then before the god, except the head, the share of the officiant, which he usually takes to his home: as a general rule none of the flesh may be removed from the sacred place. This last precaution may imply nothing more than that the flesh is regarded as sacrosanct or tabu, and it is a fact that many high castes, like the Nambuntiri Brahmans of Malabar, the most conservative of Hindus, who aim at

'J. Fergusson, J. Burgess, The Cave Temples of India, 471; V. A. Smith, History of Fine Art in Istia and Coylon, 215, with a photograph.

'See M. Ilang, Essays on the Sacred Langwage, Writiugs, aud Kadigion of the Parsis, 128.

'See the remarks on Ilausa arcrifices, A. J. N. Tremearne, The Ban of the Bori, 239 f. On the mysterious power of blood, A. A. Macdonell, A. B. Keith, Vodic Index, ii. 146.

Op. cii. 144. 


\section{The Cults of the Mother Goddesses in India.}

following the ancient Vedic rites, never eat meat except that of a sacrificed victim. ${ }^{1}$ The use of the sacred rice of Jagannath by the Kandhs seem to be sacramental. But sacrifice in India usually takes the form of a gift to the god, for which in return material benefits are expected, and the evidence for the existence of the communal type is not quite convincing.

The latest and most objectionable phasc of Mother worship is Saktism, the worship of the active female principle (prakriti), as manifested in the goddesses, consorts of Siva. ${ }^{2}$

The account of Mother worship here given is merely a sketch of an extremely complex subject, regarding which our knowledge is still defective. Much has been done to elucidate it by Bishop Whitehead, Mr. F. J. Richards, and other writers, principally for southern India. It may be hoped that the outlines which I have given will stimulate further inquiry, and provide further information which may throw much-needed light on the special developments of the cultus in Crete, Early Greece, and Western Asia.

' Vishuu Parima, iii, II, trans. II. II. Wilson, 1840, p. 307; Manu, Laws, v. 7 ; Bombay Gasettecr, xviii. 5 ; Thurston, op. cit. v. 235 ; E. W. Hopkins, up. ait. 185 note, 288 note. "In the Vedic texts no Kshatriya can eat of the sacrificial offering (Aitartya Brhhmana, vii. 26), no doubt because only the Brahmanas were kufficiently holy to recelve the divine essence of the sacrifice into which, hy partaking of it, the deity has entered in part " (A. A. Macdonell, A. B. Keith, ledic Index, i. 112, ii. 83, 145).

N. Macnical, Indian Theism from the Vedic to the Aluhmmadan Pariod, 180 et segy. : Ilopkins, of. cit. 489 et segq. ; A. Avalon, Tantra of the Great liberation, Iymms to the Goddess, Principles of Tantra. 